Croux, F., Brosens, D., Vandevelde, S., \& De Donder, L. (In press). Foreign National Prisoners in Flanders (Belgium): Motivations and Barriers to Participation in Prison Programmes. European Journal of Criminal Policy and Research.

\title{
Foreign National Prisoners in Flanders (Belgium): Motivations and Barriers to Participation in Prison Programmes
}

\begin{abstract}
This exploratory study examines the experiences of foreign national prisoners and the motivations and barriers to their participation in prison programmes (e.g., educational courses, use of the prison library, prison work, sociocultural activities, sports). Data are derived from 15 individual interviews with foreign national prisoners in two Belgian prisons. During the interviews the strengths-based approach of Appreciative Inquiry was used. The results demonstrate that foreign national prisoners experience motivations and barriers that can be placed at the different levels of the ecological model of Bronfenbrenner (1979) which affect individual behaviour: micro-, meso-, exo- and macro-level. Foreign national prisoners were often motivated to participate in prison programmes to improve their health (micro-level) or to facilitate contact inside and outside prison (meso-level). The reverse was also possible; foreign national prisoners were limited in their participation in prison programmes by their social networks (meso-level) and a lack of knowledge and understanding of the available activities (exo-level). In conclusion, limitations, guidelines for further research and implications for practice and policy are considered.
\end{abstract}

Keywords: Foreign national prisoners, Participation, Motivations, Barriers, Prison programmes

\section{Introduction}

On average, the European prison population includes $22.1 \%$ of foreign national prisoners, but there is significant variation between European countries. Some countries have almost no foreign national prisoners (e.g., Romania: 0.9\%, Moldova: 1.1\%, Albania: 1.5\%), while others have a high proportion (e.g., Switzerland: 71\%, Luxembourg: 73.6\%, San Marino: 100\% - Aebi et al. 2016). In recent years, Belgium has also experienced an increasing proportion of foreign national prisoners. In 1980, 1,212 (21.4\%) of the Belgian prison population were of non-Belgian nationality (Beyens et al. 1993), while this number had increased to 5,146 (40.1\%) by 2015 (Aebi et al. 2016). In 2015, there were more than 130 different nationalities in Belgian prisons. Moroccans, followed by Algerians and Romanians, constituted the largest group of foreign national prisoners (FOD Justice 2016).

A growing body of research shows that foreign nationals experience a number of shared needs and experiences (Barnoux and Wood 2013; Bhui 2009; Bosworth 2011; Ugelvik 2014) that are different from those of national prisoners (Bosworth 2011; Ugelvik 2014). Foreign national prisoners face language problems, difficulties in maintaining family contact and uncertainty concerning their immigration status (Barnoux and Wood 2013; Bhui 2009). However, little research focuses on foreign nationals' participation in prison programmes. Yet, it is increasingly recognized that participation in prison programmes has several positive effects for both prisoners, prison environment and society. Programme participation during imprisonment involves, for instance, opportunities for self-development, contribution to self-image (Coyle 2009; Lippke 2003; 
Parker et al. 2014), enhanced basic skills (Vacca 2004) and social competences (Lippke 2003; Parker et al. 2014). Moreover, prisoners' involvement in prison programmes contributes to a better dynamic security within prison (Edgar et al. 2011), reduces the involvement in disciplinary violations during time of imprisonment (Meek and Lewis 2014) and leads to less recidivism (Kim and Clark 2013). In this study, prison programmes include educational courses, use of the prison library, prison work, sociocultural activities, sports activities and vocational training. The available knowledge indicates that foreign national prisoners do not have the same opportunities to participate in prison programmes as national prisoners (Atabay 2009; Brosens et al. 2016; van Kalmthout et al. 2007). This is problematic as both groups have equal rights in relation to programme participation in prison (Council of Europe 2012). Furthermore, few studies take both motivations and barriers to participation in prison programmes into consideration (Brosens 2013), and even less is known about the motivations and barriers that affect the participation of foreign nationals in prison programmes (Westrheim and Manger 2014). Moreover, previous research on the participation of foreign national prisoners does not focus on the range of activities offered (e.g., Brosens et al. 2016; Westrheim and Manger 2013, 2014), although prisoners often participate in different activities (Brosens et al. 2015). Therefore, this paper will examine foreign nationals' motivations for participating in prison programmes and the barriers they experience.

\section{Participation of Foreign National Prisoners in Prison Programmes}

Except for the rights associated with their freedom, prisoners retain all their human rights while incarcerated (Coyle 2009). At the international level, the Standard Minimum Rules for the Treatment of Prisoners (United Nations 1955) and the European Prison Rules (Council of Europe 2006) clarify the right of all prisoners to participate in prison programmes. In particular, for foreign national prisoners, the Council of Europe (2012) recommends that its member states should ensure that educational and vocational training is as effective as possible for foreign nationals, and that exercise and recreational activities should be arranged flexibly to enable foreign national prisoners to participate in ways that respect their culture. In Flanders (Belgium) there is a decree concerning 'the organization of services and assistance for prisoners', stipulating that 'all' prisoners must have access to a selection of high-quality programmes encompassing culture, education, health, sports, vocational training and well-being (Flemish Government 2013).

However, in daily practice, foreign nationals are seldom able to exercise their rights as effectively as national prisoners, as they are often excluded from participating in different prison programmes (van Kalmthout et al. 2007). Studies have shown that the rate of participation in prison programmes is lower among foreign national prisoners than among the general prison population (e.g., Atabay 2009; Westrheim and Manger 2014). For instance, due to language barriers, foreign nationals have fewer opportunities to participate in educational courses (Brosens et al. 2016; van Kalmthout et al. 2007; Westrheim and Manger 2014), sociocultural activities (Snacken 2007), vocational training, release programmes (Atabay 2009), or prison work (van Kalmthout et al. 2007). In particular, a lack of information regarding opportunities for participation deters foreign national prisoners from taking part in education and vocational training (Westrheim and Manger 2014). Moreover, prison authorities often do not recognize the need to invest in reintegration programmes because foreign national prisoners often choose to return to their homeland after release (van Kalmthout et al. 2007), or face deportation (Bhui 2004). Furthermore, foreign nationals also have fewer opportunities to work in prison due to a shortage of places (van Kalmthout et al. 2007). They also have fewer opportunities to visit the prison library, as it is a 
challenge for prison libraries to provide adequate foreign language collections (Bowe 2011; Ljødal and Ra 2011), and the offer in foreign languages therefore tends to be limited (Bhui 2004; van Kalmthout et al. 2007). In general, foreign nationals do not have fewer opportunities to participate in sport (van Kalmthout et al. 2007). Previous research has demonstrated that participating in sports activities is helpful in developing language skills (Doherty and Taylor 2007).

\section{The Ecological Approach: Motivations and Barriers to Participation in Prison Programmes}

Given the positive outcomes related to participation in prison programmes, it would be interesting to have a better insight into the motivations and barriers to participation of specific groups in prison (Brosens 2013), in particular foreign nationals (Westrheim and Manger 2014). Based on existing research, different theoretical models and categories can be applied to categorize motivations and barriers to participation. For instance, Manger et al. (2010) identified three motivational categories to participate in prison education: (1) "to prepare for life upon release", (2) "social reasons and reasons unique to the prison context", and (3) "to acquire knowledge and skills” (p. 535). The research of Manger et al. (2010) focuses mainly on individual-related motivations and pays less attention to other types of motivations. In terms of participation barriers, prior research uses often either a broad classification (e.g., two-dimensional division of internal or external barriers to the individual) or a narrow classification (e.g., barriers as independent, single items - Gyurcsik et al. 2006). Consequently, a useful model to classify foreign nationals' motivations and barriers to participating in prison programmes, is Bronfenbrenner's ecological model (1979). This model clarifies the interaction of an individual with his or her environment and consists of four levels which affect individual behaviour: the micro-, meso-, exo-, and macro-level (Bronfenbrenner 1979). As this ecological model takes not only different levels into account that affect an individual behaviour (i.e., micro-, meso-, exo- and macro-level), in contrast to the research of Manger et al. (2010), it provides also a more nuanced overview of those affecting levels, opposed to prior research that uses often a broad classification in terms of barriers internal (i.e., micro-level) or external (i.e., meso-, exo-, and macro-level) to the individual. The utility of the ecological approach has already been showed in research into sports' participation outside prison (Gyurcsik et al. 2006) and in criminological research on the impact of parental incarceration on families and children (Arditti 2005). Recently the ecological theory has been adapted to participation in prison programmes (Brosens 2013). To date, the framework has only been used to study motivations for participation and barriers in the general prison population (e.g., Brosens 2013; Halimi et al. 2017). In particular, the scoping review of Brosens (2013) demonstrated that research on prisoners' programme participation is rather scarce and that it concentrates mainly on micro- and exo-related factors for participation in prison programmes. This review was of particular value for this study as it situated prisoners' motivations and barriers for participation from the existing empirical evidence in the different levels of the ecological framework. Moreover, the study of Halimi et al. (2017) studied prisoners' motivations to participate in prison education on micro- and meso-level and found that most motivations were situated at the micro-level. To our knowledge, the ecological model has never been applied to foreign nationals' participation in prison programmes. The different levels of the framework and some examples of prisoners' motivations and barriers to participating in prison programmes that are described in the literature will be discussed below. However, most of the associated literature is applicable to the entire prison population, unless explicitly stated. 
First, the micro-level, consists of features which relate to the individual (Bronfenbrenner 1979) that stimulate or impede participation in prison programmes (Brosens 2013). Examples of motivations on this level are remaining healthy (Spark and Harris 2005) and acquiring knowledge and skills (Manger et al. 2010). Moreover, the desire to reduce their sentence (Pelissier 2004) or trying to influence the parole board could be motivations for prisoners to get involved in prison programmes (Rosen et al. 2004). Barriers on the micro-level are a lack of motivation (Meyer et al. 2014) and poor physical health (Lee 1996). Research of Manger et al. (2010) demonstrates that foreign national prisoners are even more motivated to participate in prison education to gain knowledge than national prisoners. No literature has been found on foreign national prisoners' barriers at the micro-level. Secondly, the meso-level refers to interactions within the direct environment (Bronfenbrenner 1979). In prison this includes social interactions with other prisoners, prison guards, prison directors, activity providers, family, friends and lawyers (Brosens 2013). A reason for participation could be to initiate or maintain contact with fellow prisoners (Brosens et al. 2014; Lee 1996). The reverse is also possible, as fellow prisoners can be a reason for non-participation. Some prisoners are afraid of being perceived by other prisoners as 'soft' due to their programme participation and want to avoid the associated bullying (Brosens et al. 2014). A motivation for foreign nationals to participate in prison labour and education is to be able to look after their family (Westrheim and Manger 2014). Thirdly, the exo-level recognizes the role of organizations in affecting behaviour (Bronfenbrenner 1979). In a prison setting, this encompasses prison conditions and institutional practices (Arditti 2005). No exo-related motivations have been found in the existing empirical evidence. Exorelated barriers include a lack of programmes (Meyer et al. 2014), overcrowding, or a shortage of prison guards to accompany prisoners to the activities (Lee 1996). In particular, for foreign national prisoners a lack of information, information being available only in English or the language of the host country (Westrheim and Manger 2014) and the language in which the activities are offered impede their participation in prison programmes (Atabay 2009; van Kalmthout et al. 2007). Finally, the macro-level underlines the wide impact of culture, values, norms and policy (Bronfenbrenner 1979). In relation to the prison environment this implies national policy and crime regulations (Arditti 2005). No motivations on the macro-level have been found. Macro-related barriers include the limited funding for prison programmes and facilities (Lee 1996). Literature specifically focusing on foreign nationals' motivations and barriers on the macro-level has not been found.

\section{Aim}

To date, there has been limited research on prisoners' participation in programmes (Brosens 2013). Studies that concentrate on foreign nationals' participation is even more rare, as they are often excluded from research (Yildiz and Bartlett 2011), despite their specific needs (Council of Europe 2012). This study aims to fill this research gap and tries to gain insight into foreign nationals' motivations and barriers to participating in prison programmes. The group of foreign national prisoners in Belgium deserves special attention not only because of their increasing numbers (as noted above, in 1980 21.4\% of the total prison population were foreign nationals (Beyens et al. 1993), while this proportion had increased to $40.1 \%$ by 2015 - Aebi et al. 2016), but also because they are overrepresented in Belgian prisons compared to the European median (according to the SPACE I survey of 2015, the mean percentage of foreign national prisoners in European countries is 22.1\% - Aebi et al. 2016). The aim of this study is to provide answers to two research questions:

(1) How are foreign national prisoners motivated to participate in prison programmes? 
(2) How are foreign national prisoners deterred from participating in prison programmes?

\section{Methodology}

This exploratory qualitative study draws on 15 individual interviews conducted in March 2016 with male foreign national prisoners. All respondents were of non-Belgian nationality and 11 different nationalities were represented. Their age varied from 23 to 50 and the mean age was 35 years $(S D=8.46)$. Only participants who had a measure of fluency in Dutch, French or English could participate in the research because of the language skills of the researcher. Table 1 provides more information about the characteristics of the participants.

Table 1. Characteristics of the Participants

\begin{tabular}{|l|l|l|l|}
\hline Number of the respondent & Nationality & Age & Language spoken during the interview \\
\hline 1 & Rwandan & 36 & Dutch \\
\hline 2 & Burundian & 42 & English \\
\hline 3 & Congolese & 45 & French \\
\hline 4 & Palestinian & 29 & French \\
\hline 5 & Algerian & 27 & French \\
\hline 6 & Iraqi & 30 & French \\
\hline 7 & Tunisian-Italian & 34 & French/Dutch \\
\hline 8 & Algerian & 31 & French \\
\hline 9 & Dutch & 25 & Dutch \\
\hline 10 & Algerian & 23 & French \\
\hline 11 & Algerian & 29 & French \\
\hline 12 & Albanian & 41 & French \\
\hline 13 & Albanian & 35 & French \\
\hline 14 & Moroccan & 50 & French \\
\hline 15 & Albanian & 48 & French \\
\hline
\end{tabular}

As foreign national prisoners are frequently excluded from research (Yildiz and Bartlett 2011), they can be considered as an under-researched group (Brosens et al. 2015). This exploratory study interviewed 15 foreign national prisoners. Research conducted by Westrheim and Manger (2014) included 17 foreign national prisoners. Moreover, the Nordic report of Westrheim and Manger (2013) builds on data of five national studies with foreign national prisoners, those country-level studies had similar sample sizes to that of our study (i.e., Norway: $\mathrm{N}=17$, Denmark: $\mathrm{N}=16$, Finland: $\mathrm{N}=11$, Iceland: $\mathrm{N}=8$, and Sweden: $\mathrm{N}=10$ ). Since the studies of Westrheim and Manger $(2013,2014)$ are one of the few studies on foreign national prisoners' programme participation and have small sample sizes, the data obtained from our interviews should be rich enough to provide further insights into the programme participation of foreign nationals.

Prior to this study, a research protocol including information about the research goals, the data collection method, the sample, and the period during which the research would take place was approved by the national Directorate-General for Penitentiary Institutions. The Directorate-General passed on the research protocol to all prison managers of Flemish and Brussels prisons $(\mathrm{N}=18)$. A number of prison managers agreed to 
participate in the study $(\mathrm{N}=13)$. From these prisons, one prison in Brussels and one in Flanders were selected based on the proportion of foreign national prisoners and practical accessibility. Both prisons served principally as remand prisons and experienced high levels of overcrowding (FOD Justice 2016).

Before the interviews took place, activity providers and prison guards in the selected prisons compiled a list of possible interested participants. Since we wanted to include a diverse group of respondents, only a few selection criteria were put forward: (1) the respondent has a non-Belgian nationality, and (2) can express himself in Dutch, French or English. Participating in activities was not a condition to be involved in the research. It is not clear how many 'eligible' respondents were on the recruitment list, as this was the task of the activity providers and prison guards. Later, the respondents were asked personally to take part in the study by the coordinator of the activities and the activity providers, as the researcher was not allowed to do it by herself (i.e., no permission to access the cellular part of the prison). Previous research had shown the effectiveness of this personal approach in encouraging participation in research studies (Brosens et al. 2015). The reasons of those prisoners who did not want to participate in the research are unclear. Finally, 17 respondents were interviewed, whereof two were excluded as they had the Belgian nationality. The interviews in the Brussels prison took place in a meeting room of the activity providers inside the prison. In the Flemish prison, the interviews were held in rooms where prisoners normally met their lawyers/social workers. In both prisons, prison guards transferred the prisoners to the interviews, but only the researcher was present during the interviews. Before the interviews started, the first author went through the informed consent in detail with the participants, as some of the respondents were not able to read it. By so doing, we informed them about the research goals; that participation was voluntary and that they could withdraw at any time; that confidentiality and anonymity was guaranteed; and that the interview would be tape-recorded and transcribed verbatim. All the respondents signed the informed consent, where they declared to be informed and gave their agreement to participate in the research. The shortest interview lasted 41 minutes and stopped earlier because visiting hours had ended. The longest interview lasted 119 minutes. The interviews lasted on average 66.53 minutes $(S D=22.34)$.

The interview guide aimed to generate knowledge about the reasons why prisoners do or do not take part in activities, their experiences, and their needs and wishes in relation to programme participation. All the questions were open-ended. In contrast with much prison research that uses a 'problem-oriented' approach (Liebling et al. 2001), this study used the Appreciative Inquiry method. This method does not focus on the failings, shortcomings or problems of individuals and organizations, but rather on achievements, opportunities and strengths (Kadi-Hanifi et al. 2014) and is aimed at asking positive questions to realize action and dialogue (Ludema et al. 2001). In its fullest extent, Appreciative Inquiry consists of four stages, the so-called 4-D cycle: (1) discovery ('the best of what is or has been'), (2) dreaming ('what might be'), (3) design ('what should be') and (4) destiny ('what will be') (Carter 2006, p. 48). During the data collection 'Appreciative protocols' are used which are somewhat unstructured instruments (Robinson et al. 2012). However, the interview guide used in this research was rather semi-structured and covered the first two stages of Appreciative Inquiry, namely the discovery and dreaming phase. This tentative approach seemed methodological justified since Appreciative Inquiry was used as a 'mode of inquiry' (i.e., understanding practices and organisations) instead of a 'mode of transformation' (i.e., changing practices and organisations - Robinson et al. 2012). We asked, for instance, questions such as: "What is the best activity in which you participated here in prison?" or "If you could change something about the activities organized in prison, what would you like to change?". 
All individual interviews were recorded and transcribed verbatim. The qualitative analytical programme MAXQDA was used to analyse the data. Labels or codes were assigned to the transcribed manuscripts of the individual interviews. On the one hand, the construction of the labels was done deductively (i.e., based on a framework used in previous quantitative research about the programme participation of the prison population (Brosens et al. 2013)). The research used Bronfenbrenner's ecological model (1979), to assign the labels to the data. On the other hand, the labels were created from the data. In the results section, we added some quotes from the respondents, which were made more intelligible and were translated by the researcher to English.

\section{Results}

This section provides an overview of the main results of our study with focus on (1) foreign nationals' motivations for participating in prison programmes, and (2) barriers to their participation in programmes. The motivations and barriers are categorized as outlined by Bronfenbrenner's ecological model (1979), and now applied in the prison context (Brosens 2013).

\section{Motivations of Foreign National Prisoners for Participating in Prison Programmes}

Foreign nationals expressed different motivations for participating in prison programmes on micro- and mesolevel. On a micro-level, respondents participated in prison programmes because they gained knowledge, enjoyed it or found the programmes interesting. They participated in prison programmes to increase their job opportunities outside prison: 'I am doing vocational training. (...). When I am released, I will have a certificate so I can work' (R8, Algerian, 31, French). This motivation was mentioned by respondents who were planning to return to their homeland, but also by respondents who lived in Belgium before their period of imprisonment and wanted to stay in Belgium after their release from prison. Foreign nationals also gave reasons that were mainly linked to one specific activity. For instance, improving health was mentioned as the main reason for participating in sports. This concerned both physical health (e.g., to stay in shape, improve their physical condition or stay away from cigarettes), and mental health (e.g., relaxing, reducing stress and working off aggression/hate): 'That is to keep your mind a little bit healthy in prison because it is heavy in prison' (R9, Dutchman, 25, Dutch). Another prisoner said: 'It is good for the spirit. It is good for everything' (R12, Albanian, 41, French). Furthermore, foreign nationals undertook prison work to earn money. Respondents worked inside prison to buy products from the canteen or to rent a television, which they said was expensive. Different respondents also expressed a desire to be able to lead as normal life as possible: 'In my head, I am going to work. They pick us up at 7.30 and you finish at 14.30, it is like someone who has a normal life outside' (R3, Congolese, 45, French). Creating a distraction, giving some variety to the day, passing time, or making the time pass more quickly and the possibility of leaving the cell were also mentioned as motivations for taking part in programmes: 'But yes, it is almost the same for all the activities in prison that I like to attend: not staying in the cell during the whole day' (R13, Albanian, 35, French). One respondent told us that he collected all the diplomas he had received as a result of his participation in prison programmes to show them to the sentencing court, in the hope of influencing it.

On the meso-level, social contacts were the main driver for participation in activities. The ability to meet other prisoners, to talk with teachers, or the group atmosphere played an important role for foreign nationals' participation in prison programmes. Participants with family abroad mentioned that they rarely or never received visits and wished to have more social contact. One respondent said he wanted to go to the cinema 
inside prison to find a girlfriend (among the female prisoners watching the same movie). Different respondents also preferred group activities: 'A group is better because you learn a lot from the group' (R2, Burundian, 42, English), 'I find it better in a group because it encourages you' (R4, Palestine, 29, French), but also because it was more fun. Moreover, respondents cited prison work as helping to pay compensation to the victims of their crimes, to offer financial support to their families or to be able to make telephone calls. Different interviewees complained about the high cost of making telephone calls abroad. Other participants wanted to be able to use Skype to enable them to keep in contact with their relatives for free. In addition, there was a high level of willingness among the participants to learn languages. Some respondents had attended language courses in another prison or outside prison before their imprisonment and wanted to resume these courses. There was particular interest in Dutch language courses among participants who had stayed in Belgium/the Netherlands before their detention period and planned to stay after their release: 'It is very important for me to do the course to gain a better understanding of the Dutch language. I have a diploma from a Dutch course but I still need to do more courses about it' (R2, Burundian, 42, English). Different respondents emphasized the importance of learning languages for foreign nationals, for instance, to facilitate contact within the prison:

'When I arrived in prison I had a lot of difficulties. I mean in communication with others. Sometimes I had to ask people to explain what was written on the paper and that is why I started to speak, to read, to write and to understand the language' (R4, Palestine, 29, French).

Learning languages also occurred outside formal educational courses, for instance through self-tuition or social interactions. One respondent said he preferred to share a cell with Dutch prisoners to learn the language. The desire to speak Dutch related not just to their interactions within prison, but also outside prison, to facilitate communication with their family members. As noted above, interviewees who had lived in Belgium/the Netherlands before their detention and wanted to stay there after their release from prison were particularly keen to learn Dutch:

'She (his wife) is Flemish and my children... It is a pity that they do not speak Arabic. They only speak Dutch and therefore I am obliged to learn the Dutch language to be able to speak with my children. I do my best. I read the newspapers, I read books, I read the subtitles on television' (R7, Tunisian-Italian, 34, French/Dutch).

Those participants who wanted to stay in Belgium after their release emphasized that speaking Dutch was important for their reintegration: 'I would prefer to live in Flanders after my release. I find that living in Flanders without speaking good Dutch is a little bit tricky' (R3, Congolese, 45, French). Finally, some respondents reported that other prisoners recommended certain programmes to them: 'I met some good people who have been in prison for a long time and they advised me: "Always do sports, because then you are not going to think about the limited family contact"' (R9, Dutchman, 25, Dutch). Another interviewee mentioned that he kept going to the educational classes as the teacher motivated him to keep on studying. 


\section{Barriers that Discourage Foreign National Prisoners from Participating in Prison Programmes}

Despite the high levels of willingness among the respondents to participate in prison programmes, they experienced different barriers at the micro-, meso- and exo-level. On the micro-level, some participants reported that they rarely went to the library - or did not go at all - because they possessed their own reading materials, even though the prison library offered materials in several foreign languages. However, according to different respondents, the library had a limited offering, as books in the respondents' native language were not always available. Furthermore, some form of injury, a lack of interest, a dislike for a particular activity and not feeling well were reasons cited by respondents for not participating in prison programmes.

In addition, respondents also reported some barriers at the meso-level. One interviewee mentioned that several of his family members had passed away during his incarceration, and therefore he was not in the mood to participate. Another participant reported that prison guards were not always supportive of programme participation: 'When you do a course, you notice that some prison guards do not agree with it. They are not happy to see you going upstairs to learn something. You have to stay locked up in your cell' (R1, Rwandan, 36, Dutch). Fellow prisoners might also constitute a barrier to participation. Some did not participate to avoid problems with other prisoners, out of fear or to prevent them from causing problems:

'I do not like to leave my cell too much because when I leave my cell, I am afraid. I am not afraid of the people who hit me, but I am afraid that I am going to do something stupid. In that case I say no' (R7, Tunisian-Italian, 34, French/Dutch).

Finally, foreign nationals also experienced barriers at the exo-level. Overlapping prison programmes (e.g., overlap between different prison programmes or between the daily walk/visit and prison programmes) forced the prisoner to choose between different activities. This did not mean they never participated in anything, but often they preferred to be involved in another activity:

'I go to the fitness training when it is possible because, even in the open section, fitness training is at the same time as the daily walk. You have to choose: going to the fitness training or for the daily walk. It would be better if they organized the fitness training after the daily walk' (R7, Tunisian-Italian, 34, French/Dutch)

A lack of appropriate courses adapted to the needs of foreign national prisoners was also mentioned. First, foreign nationals said that they were deterred from participating in prison programmes because of the language in which the activities were offered, as they required a good understanding of the Dutch language. Several interviewees did not speak Dutch and were therefore not allowed to participate: 'I asked to do a course to become a welder. He (the activity provider) said: "You are obliged to speak Dutch"' (R10, Algerian, 23, French). Another respondent reported that the language itself held him back from participating: 'If courses were offered in French, it would be better but when they are not offered in French, only in Dutch, it is difficult for me because I do not understand Dutch' (R5, Algerian, 27, French). The main language courses offered in the Flemish prison were 'Dutch as a second language', but several respondents considered this as being of little use for their future because Dutch was not spoken in their homeland. This did not mean there was no interest in 
attending other language courses: 'I am going to return to my country and there they do not speak much Dutch but there are some French companies. There are a lot of mines and gas companies in Albania and there it is good to know French' (R12, Albanian, 41, French).

Participants indicated that there was insufficient information about the activities on offer. One respondent reported being inadequately informed about the rules concerning prison work, and because of this he received a penalty and he could no longer work. However, sometimes the information was available, but was not intelligible for foreign nationals. A lack of information was often linked to the language problems faced by the respondents, but participants who spoke (a little bit of) Dutch also suffered a lack of information. The information channels to announce the activity offer (e.g., leaflets, posters, internal TV-channel - i.e., a channel on television to inform prisoners about various aspects of prison life) were not always appropriate due to language barriers. The interviews demonstrated the need for better communication between prison guards and foreign nationals: 'Sometimes we have the right, but they do not say anything or say what kind of activities are organized in prison' (R1, Rwandan, 36, Dutch). Moreover, one interviewee reported barriers related to the current status of his detention period. He did not work because he had just been transferred to another prison. Before he would agree to participate, he wanted to discuss his opportunities to carry out prison work with a probation officer from his homeland. Furthermore, the poor condition of the materials and infrastructure constituted barriers:

'There is not enough air and that is not good (...). That is why I sometimes go and sometimes do not go to the fitness training. Besides, the fitness training equipment is very old. They have been here since the prison was opened' (R7, Tunisian-Italian, 34, French/Dutch).

In addition, limitations on the activities offered constituted a significant barrier. For example, the outdated and limited offer regarding genres and languages in the library was mentioned as a barrier:

'I never went to the library because I do not read French. I can only read my languages: Albanian and Greek. A lot of friends here said to me: "There are no books in Albanian and Greek here in prison." And that is why I have never written a request to visit the library’ (R13, Albanian, 35, French).

Furthermore, some respondents were not able to participate because of staff shortages: 'Sometimes we do not have activities during the whole week. We do not have activities when there are no prison guards. That interrupts the activity offer that was going on' (R11, Algerian, 29, French). Furthermore, the prisoners' opportunities for participation could be affected by the characteristics of the wing in which they were housed (e.g., a closed or an open section). According to one respondent, he was in the closed section because of his status as a foreigner, which he viewed as racism. Some participants indicated they had fewer opportunities to participate than their fellow prisoners in other sections, which they found unfair:

'For us they do not organize concerts. I have seen it on the internal TV-channel. There will be a rock group for the Women's Section, Drug-free Section and men in Section 2, but not for the men on Section 1' (R9, Dutchman, 25, Dutch). 
Waiting lists and a lack of activities were also cited as barriers. As a result, some respondents asked to be transferred to other prisons with more extensive activity offers. Receiving no answer from activity providers to requests to register for an activity or not being invited to become involved in prison programmes were also cited as barriers. One interviewee had been able to overcome this type of barrier: 'I have written several requests. They did not accept until I said to the people who went to school: "Please, ask the teacher to call me". Finally, he called me' (R12, Albanian, 41, French). Another respondent reported not going to fitness activities because he could go only once a week. If he had been able to go more than once a week, he would have liked to get involved. Finally, one prisoner doubted the effectiveness of the Dutch courses and wanted to stop.

\section{Discussion}

This research investigates the reasons underlying foreign nationals' (non-)participation in prison programmes. The study demonstrates that the motivations for participating in prison programmes and the barriers to doing so occurred at the different levels of Bronfenbrenner's ecological framework (1979). Due to the fact that there is only limited research available on foreign nationals' participation in programmes (with a few notable exceptions e.g., Westrheim and Manger 2013, 2014), we place our results also within the literature about programme participation among the general prison population.

Looking at motivations on the micro-level, there were a number of important findings. Foreign nationals participate in prison programmes to enhance their job opportunities. Although Westrheim and Manger (2013) demonstrated that many foreign national prisoners are pessimistic about their future job prospects, the participants in our study were quite hopeful of finding a job. A possible explanation for their more positive view of the future might lie in our methodology (i.e., Appreciative Inquiry). However, other explanations are possible including the prison context and differences between countries. Future research can bring clarity about this. One motivation for foreigners to participate in prison work is to earn money. As they often receive little or no financial support from family or friends, they are more reliant on earnings from prison work than national prisoners are (Atabay 2009; van Kalmthout et al. 2007) to buy food, telephone cards, personal hygiene products or TV-rental (van Kalmthout et al. 2007). Moreover, they express a need for normalization (i.e., to feel they lead a normal life, be distracted, be able to leave their cell, vary their daily routine, to pass the time and to make the time pass more quickly), which is considered as an important motivation by foreign nationals. Previous research among the general prison population has also shown that prisoners are motivated to participate in educational courses by the desire for normalization (Halimi et al. 2017). Moreover, foreign national prisoners were motivated to participate to gain knowledge. According to the study of Manger et al. (2010) foreign national prisoners are even more likely to mention such a motive than national prisoners. The desire to improve physical and/or mental health is another important reason that foreign nationals have for participating in sports activities. This is consistent with previous research among the general prison population, which states that prisoners who participate in sports activities benefit from better physical (Gallant et al. 2015) and mental health (Nelson et al. 2006).

Secondly, on the meso-level, our study results underline the fact that taking part in programmes can be seen as a means of socializing (van Kalmthout et al. 2007). In turn, this can help to compensate for the difficulties they experience in maintaining family contact, which is a particular difficulty experienced by foreign 
national prisoners (Barnoux and Wood 2013; Bhui 2009). This can happen in a 'direct' form, such as social contact with fellow prisoners and prison guards, but also in 'indirect' ways, such as earning money to be able to make telephone calls to family (abroad) and support their family financially. These social contacts also reinforce the motivation to participate in prison programmes. Research of Manger et al. (2010) even states that foreign national prisoners report more social reasons to participate than national prisoners. Prisoners often participate on the basis of recommendations from fellow prisoners. This is in line with previous research which demonstrates that prisoners inform each other about the existence of prison programmes (Brosens et al. 2014).

Despite their willingness to participate in prison programmes, foreigners also face various barriers. At the micro-level, possessing their own reading materials, an injury, a lack of interest, not liking a particular activity and not feeling well were reasons cited by foreign prisoners for not participating in prison programmes. Given the severe impact that detention in a foreign country has on the mental health of foreign nationals (Barnoux and Wood 2013), it is important that activity providers are aware of the possible negative influence that such mental health problems can have on foreign national prisoners' participation in programmes.

In addition, at the meso-level, the results demonstrate that interactions with family members outside prison, and with prison guards and fellow prisoners discouraged participation in programmes by foreign nationals. Research among the general prison population reveals the barriers that social networks can put up against participation (Brosens et al. 2014).

Finally, the findings indicated several barriers at the exo-level. Some activities overlapped, meaning that prisoners were forced to choose between activities and this constituted a barrier to participation by foreign nationals. This barrier has been confirmed by the research of Batchelder and Pippert (2002) among the entire prison population. Their research shows that prisoners must choose between education and engaging in prison work. The language in which the activities were offered also discouraged participation by foreign nationals. Previous research has also demonstrated that foreign national prisoners face language barriers when participating in programmes (Atabay 2009; van Kalmthout et al. 2007). Furthermore, the fact that the ability to speak Dutch is of no use in their homeland means that foreign prisoners are less likely to participate in Dutch language courses. However, this does not mean they lack the motivation to attend other language courses. Research carried out by Westrheim and Manger (2014) revealed that foreign nationals who plan to return to their homeland would value English language courses because of the expected benefits in their homeland. Another issue is that foreign nationals may not be aware of the possibility of participating in prison programmes, and this can constitute another barrier. Westrheim and Manger (2014) showed that foreign national prisoners suffer from a lack of information in a language that they can understand regarding opportunities to participate in programmes. Other barriers to participation include the status of prisoners' detention period, a lack of resources or the poor condition of materials and infrastructure, staff shortages, not being invited to join activities, being housed in a particular section, a lack of activities, waiting lists and receiving no response from activity providers to requests to register for activities. According to Brosens et al. (2015), the structure of the prison places constraints on prisoners' agency. Related to this research, it seems that foreign national prisoners' agency (i.e., their opportunities to participate in prison programmes) is reduced by barriers at the exo-level, which can be related to the prison structure. 


\section{Ethical considerations}

Doing research in prison involves several ethical implications (Gostin et al. 2007), in particular with foreign nationals as they can be considered as a specifically vulnerable group of prisoners (Westrheim and Manger 2013). Giving foreign nationals the possibility to speak a language in which they feel themselves comfortable is about respecting respondents (Westrheim and Manger 2014). This study did not use an interpreter due to financial constraints. However, the respondents were given the choice to participate in the research and had the possibility to withdraw at any moment without any consequence. As none of the participants mentioned this as an issue, we feel we never disrespect them by asking to conduct the interview in another language. In addition, some ethical considerations can be formulated about the use of the Appreciative Inquiry method. This method may place great 'demands' on foreign nationals, although the respondents never mentioned this during the interviews. If this would have happened (e.g., if people would have felt embarrassed or insecure), persons could have been referred to the contact person (i.e., coordinator of the activities) in prison to follow them up. When we asked the respondents questions about the 'best activity' in which they participated, sometimes respondents indicated that there was no 'best activity'. Consequently, we reformulated the question to 'an activity they really enjoyed' to keep the interview going. In conclusion, we would like shortly comment on the profile of the researcher involved in the data collection. It is difficult to know to what extent there was an imbalance between the 'foreign national male participant' and the 'white female researcher' and to what extent this had an influence on the participants. We never felt that this was a problem, as many respondents were very respectful and happy that they had the opportunity to disclose their story to someone. However, we think it is important to be aware of the (possible) influence(s), which is something that could be explicitly asked about in future research.

\section{Limitations and Further Research}

This study has some limitations which may have affected the results. First, the findings are not generalizable to the whole population of foreign national prisoners in Belgium, as this population is in itself a very diverse group (Brosens et al. 2016; Ugelvik 2014; van Kalmthout et al. 2007; Yildiz and Bartlett 2011). This emphasizes the need to be aware of differences between different foreign national prisoners as well. Besides, we acknowledge the small number of respondents $(\mathrm{N}=15)$ involved in the study. However, also previous research conducted by Westrheim and Manger (2014), for instance, involved 17 foreign national prisoners in their qualitative study. This might be due to the fact that it is challenging to include this under-researched group (Brosens et al. 2015). Despite the small number of respondents, it seemed that data from 15 interviews was rich enough to provide some insights into the motivations of these prisoners to participate in prison programmes in Belgium and the barriers to doing so. This deserves more attention, as research on this topic is quite scarce. Moreover, it was not the aim of this research to gain more insight into foreign national prisoners' participation (rate) in particular types of prison programmes. However, it would be valuable to develop a standardized survey instrument to investigate how many foreign nationals participate in diverse prison programmes, who are the non-participants, as well as what types of prison programmes they have (not) participated in. In addition, it is not possible to make statements about foreign national prisoners' reasons whether or not to participate in particular types of prison programmes, as all activities were taken together under the term 'prison programmes'. It would be valuable for future research to study how frequently the different motivations and barriers are experienced and to which specific activity they relate. Furthermore, there seems to be some overlap between motivations for participation 
and the barriers faced by foreign nationals and national prisoners. Previous research has shown that prisoners of Belgian nationality but of foreign origin to some extent experience the same problems as foreign national prisoners, as well as facing some other problems during detention (Snacken 2007). Further research could examine the extent to which motivations and barriers differ between these different groups of prisoners.

Moreover, this study used the ecological model of Bronfenbrenner (1979) to categorize the findings, as previous research has demonstrated the utility of this framework (Arditti 2005; Brosens 2013; Gyurcsik et al. 2006; Halimi et al. 2017). Because of the interconnectedness of the different levels of the ecological model (Bronfenbrenner, 1979), difficulties were experienced during the analyses. In particular, because of the fact that the delineation of the different levels is not always clear, it was sometimes difficult to decide at which level a particular motive or barrier had to be categorized. Consequently, the categorization of the different motives and barriers was extensively discussed with the co-authors until an agreement was found. Other ways to categorize the results, such as a thematic approach (e.g., Westrheim and Manger 2013, 2014) are also possible and could be applied in further research.

Besides, knowledge of the culture, language, values and norms of respondents is an important factor for the effectiveness of the research (Nyaupane and Poudel 2012). Most interviews were conducted in a language other than the mother tongue of both the respondents and the researcher, and this may have affected the findings. In addition, only respondents who spoke Dutch, French or English could participate, due to the language skills of the researcher. Hence, several foreign nationals were excluded from the research. Therefore, this study provides insight into the participation of a limited group of foreign national prisoners. As previous research has demonstrated the effectiveness of the use of a translator during interviews (Westrheim and Manger 2014), the possibility of involving translators in future research should be explored.

Finally, some limitations and experiences concerning the use of Appreciative Inquiry can be formulated since this could be useful for further research. Given the prison context, it was a challenging experience for both the respondents and the interviewer to stay in the 'positive mode'. When the interviewees ended up in a more negative stance, it was the task of the interviewer to move them away from this negativity. However, this was not problematic as the method of Appreciative Inquiry allows respondents to elaborate on both positive (i.e., 'the best of what is') and negative experiences (i.e., 'the worst of what is') (Liebling et al. 2001). In addition, it was hard for the participants to dream about their desired future. Many had difficulties imagining changes in prison. Respondents repeatedly said: "There is no ideal prison" or "I could never be the prison director".

\section{Implications for Practice and Policy}

The present findings have important implications for practice and policy with a view to adapting prison programmes to enable foreign nationals to participate. Building on insights at the meso-level, the important role of fellow prisoners could be seen in the form of peer support. Fellow inmates can play a role in anticipating barriers, as they can fulfil the role of peer mentor and provide support during courses (Brosens et al. 2016). They can also operate as 'insiders' and provide information about prison programmes, as well as assisting new prisoners (Boothby 2011) in different languages. Nevertheless, it is important to acknowledge some risks related to the involvement of prisoners. In case prisoners are used as translators, this can create power imbalances and conflict between prisoners (Westrheim and Manger 2013). Therefore, adequate recruitment, training and supervision of peer supporters are paramount. However, it is vital to consider peer supporters not as a surrogate 
of prison staff, but rather as an additional force (Devilly et al. 2005). As foreign national prisoners receive fewer visitors (van Kalmthout et al. 2007) and often desire more social contact, activity providers can highlight the benefits resulting from participation, such as the ability to meet fellow prisoners and reduce social isolation. Also, in relation to language barriers, it would be helpful to eliminate language requirements for certain activities and to provide more language courses for foreign nationals (Ugelvik 2014) as well as for prison staff (Barkan et al. 2011; Barnoux and Wood 2013). Furthermore, the language problems faced by foreign nationals may also be linked to a lack of information. Therefore, activity providers need to pay special attention to the oral and written communication of prison programmes in different languages. They should also promote activities for which language proficiency is not so important (e.g., sports activities). As some foreign nationals plan to return to their homeland following release, it may be helpful to offer (online) distance learning opportunities provided by their homeland (Brosens et al. 2016). Given the fact that some foreign nationals have their own reading materials and that there are not always enough reading materials in foreign languages, prisons could offer to buy them from prisoners and store them in the prison library to extend their offer in foreign languages. Finally, national policy should be more sensitive to the situation of foreign national prisoners. In contrast to the European institutions (e.g., Council of Europe 2012), Belgian regulations do not specifically take foreign nationals into account (Lippens et al. 2009). However, it is important to consider them as a special group with specific needs (Council of Europe 2006, 2012). 


\section{References}

Aebi, M. F., Tiago, M. M., \& Burkhardt, C. (2016). SPACE I - Council of Europe Annual Penal Statistics: Prison populations. Survey 2015. http://wp.unil.ch/space/files/2017/03/SPACE_I_2015_Report_170314.pdf. Accessed 15 March 2017.

Arditti, J. A. (2005). Families and incarceration: An ecological approach. Families in Society: The Journal of Contemporary Social Services, 86(2), 251-260.

Atabay, T. (2009). Handbook on Prisoners with Special Needs. Vienna: United Nations Office on Drugs and Crime.

Barkan, M., Toprak, E., Kumtepe, A. T., Kumtepe, E. G., Ataizi, M., Pilanci, H., et al. (2011). Eliminating language barriers online at European prisons (ELBEP): a case-study. Educational Media International, 48(3), 235-248.

Barnoux, M., \& Wood, J. (2013). The specific needs of foreign national prisoners and the threat to their mental health from being imprisoned in a foreign country. Aggression and Violent Behavior, 18(2), 240-246.

Batchelder, J. S., \& Pippert, J. M. (2002). Hard Time or Idle Time: Factors Affecting Inmate Choices between Participation in Prison Work and Education Programs. The Prison Journal, 82(2), $269-280$. Beyens, K., Snacken, S., \& Eliaerts, C. (1993). Cracking walls. Overcrowded prisons: size, causes and possible solutions. Antwerpen-Arnhem: Kluwer-Gouda, Interuniversitaire Reeks Criminologie en Strafwetenschappen [In Dutch].

Bhui, H. S. (2004). Going The Distance: Developing Effective Policy and Practice with Foreign National Prisoners. $\quad$ www.prisonreformtrust.org.uk/Portals/0/Documents/going\%20the\%20distance\%20\%20\%20foreign\%20national\%20prisoners.pdf. Accessed 22 January 2017.

Bhui, H. S. (2009). Foreign National Prisoners: Issues and Debates. In H. S. Bhui (Ed.), Race \& Criminal Justice (pp. 154-169). London: SAGE.

Boothby, M. R. K. (2011). Insiders' Views of their Role: Toward their Training. Canadian Journal of Criminology and Criminal Justice, 53(4), 424-448.

Bosworth, M. (2011). Deportation, detention and foreign-national prisoners in England and Wales. Citizenship Studies, 15(5), 583-595.

Bowe, C. (2011). Recent Trends in UK Prison Libraries. Library Trends, 59(3), 427-445.

Bronfenbrenner, U. (1979). The Ecology of Human Development: experiments by nature and design. Cambridge, Massachusetts and London: Harvard University Press.

Brosens, D. (2013). Participation in prison programmes: encouraging and discouraging factors. In P. Ponsaers, A. Crawford, J. D. de Maillard, J. Shapland, \& A. Verhage (Eds.), Crime, violence, justice and social order: Monitoring contemporary security issues. (pp. 275-298). Antwerpen: Maklu.

Brosens, D., De Donder, L., Dury, S., Vanwing, T., \& Verté, D. (2015). Life Long Learning: The Prison Library as a Bridge to Participation. Procedia - Social and Behavioral Sciences, 191, 1496-1500.

Brosens, D., De Donder, L., Dury, S., \& Verté, D. (2015). Building a Research Partnership in a Prison Context: From Collaboration to Co-Construction. Sociological Research Online, 20(3), doi: 10.5153/sro.3693.

Brosens, D., De Donder, L., \& Foriner Consortium. (2016). Educational participation of European citizens detained in a foreign European country. www.foriner.com/wp-content/uploads/2016/04/Foriner-researchreport.pdf. Accessed 20 January 2017.

Brosens, D., De Donder, L., Vanwing, T., Dury, S., \& Verté, D. (2014). Lifelong Learning Programs in Prison: Influence of Social Networks on Participation. Procedia - Social and Behavioral Sciences, 116, 518-523.

Brosens, D., De Donder, L., \& Verté, D. (2013). Correctional Programmes in the Prison of Antwerp: A Research into the Needs of Prisoners.

https://k00118.login.kanooh.be/sites/default/files/media/db_onderzoeksrapport_behoefteonderzoek_gevangenis_ antwerpen.pdf. Accessed 12 January 2017 [In Dutch].

Carter, B. (2006). "One expertise among many" - working appreciatively to make miracles instead of finding problems Using appreciative inquiry as a way of reframing research. Journal of Research in Nursing, 11(1), 4863.

Council of Europe (2006). Recommendation Rec(2006) 2 of the Committee of Ministers to Member States on the European Prison Rules. https://search.coe.int/cm/Pages/result_details.aspx?ObjectID=09000016805d8d25.

Accessed 25 January 2017. 
Council of Europe (2012). Recommendation CM/Rec (2012)12 of the Committee of Ministers to member States concerning foreign prisoners. http://webcache.googleusercontent.com/search?q=cache:r3ymIY8GtA0J:pjpeu.coe.int/documents/3983922/6970334/CMRec\%2B\%282012\%29\%2B12\%2Bconcerning\%2Bforeign\%2Bpris oners.pdf/a13a6dc6facd4aaa9cc63bf875ac8b0f+\&cd=1\&hl=nl\&ct=clnk\&gl=be. Accessed 22 January 2017. Coyle, A. (2009). A Human Rights Approach to Prison Management: Handbook for prison staff. London: International Centre for Prison Studies.

Devilly, G. J., Sorbello, L., Eccleston, L., \& Ward, T. (2005). Prison-based peer-education schemes. Aggression and Violent Behavior, 10(2), 219-240.

Doherty, A., \& Taylor, T. (2007). Sport and physical recreation in the settlement of immigrant youth. Leisure, 31(1), 27-55.

Edgar, K., Jacobson, J., \& Biggar, K. (2011). Time Well Spent: A practical guide to active citizenship and volunteering in prison. https://www.ncjrs.gov/App/AbstractDB/AbstractDBDetails.aspx?id=260952. Accessed 22 December 2017.

Flemish Government. (2013). Decree on the Organisation of Care and Services for Prisoners (pp. 2245722462). Bulletin of Acts, Orders and Decrees. www.ejustice.just.fgov.be/mopdf/2013/04/11_1.pdf\#Page41. Accessed 12 January 2017 [In Dutch].

FOD Justice. (2016). Annual report 2015. Directorate-general penitentiaries.

http://justitie.belgium.be/sites/default/files/downloads/2016-06_epi_jaarverslag_2015_nl.pdf. Accessed 11 November 2016 [In Dutch].

Gallant, D., Sherry, E., \& Nicholson, M. (2015). Recreation or rehabilitation? Managing sport for development programs with prison populations. Sport Management Review, 18(1), 45-56.

Gostin, L. O., Vanchieri, C., \& Pope, A. (2007). Ethical Considerations for Research Involving Prisoners. Washington, D.C.: National Academies Press.

Gyurcsik, N. C., Spink, K. S., Bray, S. R., Chad, K., \& Kwan, M. (2006). An ecologically based examination of barriers to physical activity in students from grade seven through first-year university. Journal of Adolescent Health, 38(6), 704-711.

Halimi, M., Brosens, D., De Donder, L., \& Engels, N. (2017). Learning during imprisonment: prisoners' motives to educational participation within a remand prison in Belgium. The Journal of Correctional Education, 68(1), $3-31$.

Kadi-Hanifi, K., Dagman, O., Peters, J., Snell, E., Tutton, C., \& Wright, T. (2014). Engaging students and staff with educational development through appreciative inquiry. Innovations in Education and Teaching International, 51(6), 584-594.

Kim, R. H., \& Clark, D. (2013). The effect of prison-based college education programs on recidivism: Propensity Score Matching approach. Journal of Criminal Justice, 41(3), 196-204.

Lee, R. D. (1996). Prisoners' rights to recreation: Quantity, quality, and other aspects. Journal of Criminal Justice, 24(2), 167-178.

Liebling, A., Elliott, C., \& Arnold, H. (2001). Transforming the Prison: Romantic Optimism or Appreciative Realism? Criminology and Criminal Justice, 1(2), 161-180.

Lippens, V., Nuytiens, A., \& Scheirs, V. (2009). Different profiles, different pains! Diversity and detention experience: need for a differentiated execution of sentences? In T. Daems, P. Pletincx, L. Robert, A. van de Wiel, \& K. Verpoest (Eds.), Behind bars in Belgium (pp. 113-144). Ghent: Academia Press [In Dutch]. Lippke, R. L. (2003). Prisoner access to recreation, entertainment and diversion. Punishment \& Society, 5(1), 33-52.

Ljødal, H. K., \& Ra, E. (2011). Prison Libraries the Scandinavian Way: An Overview of the Development and Operation of Prison Library Services. Library Trends, 59(3), 473-489.

Ludema, J. D., Cooperrider, D. L., \& Barrett, F. J. (2001). Appreciative Inquiry: the Power of the Unconditional Positive Question. In P. Reason \& H. Bradbury (Eds.), Handbook of Action Research. Participative Inquiry and Practice (pp. 189-199). London: SAGE.

Manger, T., Eikeland, O., Diseth, Å., Hetland, H., \& Asbjørnsen, A. (2010). Prison Inmates’ Educational Motives: Are They Pushed or Pulled? Scandinavian Journal of Educational Research, 54(6), 535-547.

Meek, R., \& Lewis, G. E. (2014). Promoting Well-Being and Desistance Through Sport and Physical Activity: The Opportunities and Barriers Experienced by Women in English Prisons. Women \& Criminal Justice, 24(2), 
$151-172$.

Meyer, C. L., Tangney, J. P., Stuewig, J., \& Moore, K. E. (2014). Why Do Some Jail Inmates Not Engage in Treatment and Services? International Journal of Offender Therapy and Comparative Criminology, 58(8), 914930.

Nelson, M., Specian, V. L., Tracy, N. C., \& Demello, J. J. (2006). The Effects of Moderate Physical Activity on Offenders in a Rehabilitative Program. Journal of Correctional Education, 57(4), 276-285.

Nyaupane, G. P., \& Poudel, S. (2012). Application of appreciative inquiry in tourism research in rural communities. Tourism Management, 33(4), 978-987.

Parker, A., Meek, R., \& Lewis, G. (2014). Sport in a youth prison: male young offenders' experiences of a sporting intervention. Journal of Youth Studies, 17(3), 381-396.

Pelissier, B. (2004). Gender Differences in Substance Use Treatment Entry and Retention Among Prisoners With Substance Use Histories. American Journal of Public Health, 94(8), 1418-1424.

Robinson, G., Priede, C., Farrall, S., Shapland, J., \& McNeill, F. (2012). Doing "strengths-based” research: Appreciative Inquiry in a probation setting. Criminology and Criminal Justice, 13(1), 3-20.

Rosen, P. J., Hiller, M. L., Webster, J. M., Staton, M., \& Leukefeld, C. (2004). Treatment Motivation and Therapeutic Engagement in Prison-Based Substance Use Treatment. Journal of Psychoactive Drugs, 36(3), 387396.

Snacken, S. (2007). Belgium. In A. M. van Kalmthout, F. B. A. M. Hofstee-van der Meulen, \& F. Dünkel (Eds.), Foreigners in European Prisons (pp. 127-156). Nijmegen: Wolf Legal Publishers.

Spark, C., \& Harris, A. (2005). Vocation, vocation: A study of prisoner education for women. Journal of Sociology, 41(2), 143-161.

Ugelvik, T. (2014). The Incarceration of Foreigners in European Prisons. In S. Pickering \& J. Ham (Eds.), The Routledge Handbook on Crime and International Migration (pp. 107-120). London \& New York: Routledge. United Nations. (1955). Standard Minimum Rules for the Treatment of Prisoners.

http://www.refworld.org/docid/3ae6b36e8.html. Accessed 28 October 2015.

Vacca, J. S. (2004). Educated Prisoners Are Less Likely to Return to Prison. Journal of Correctional Education, 55(4), 297-305.

van Kalmthout, A. M., Hofstee-van der Meulen, F. B. A. M., \& Dünkel, F. (2007). Comparative overview, Conclusions and Recommendations. In A. M. van Kalmthout, F. B. A. M. Hofstee-van der Meulen, \& F. Dünkel (Eds.), Foreigners in European Prisons (pp. 7-88). Nijmegen: Wolf Legal Publishers.

Westrheim, K., \& Manger, T. (2013). Educational background, preferences and needs. A qualitative study of prisoners from Iraq, Poland, Russia, Serbia and Somalia.

www.nordvux.net/portals/0/_dokumenter/2013/educational_background.pdf. Accessed 24 January 2017. Westrheim, K., \& Manger, T. (2014). Iraqi Prisoners in Norway: Educational Background, Participation, Preferences and Barriers to Education. Journal of Prison Education and Reentry, 1(1), 6-19.

Yildiz, C., \& Bartlett, A. (2011). Language, foreign nationality and ethnicity in an English prison: implications for the quality of health and social research. Journal of Medical Ethics, 37(10), 637-640. 